\title{
ACTIVITY AND ISOZYME CONTENT OF LACTATE DEHYDROGENASE UNDER LONG-TERM ORAL TAURINE ADMINISTRATION TO RATS
}

\author{
R. D. OSTAPIV $V^{1,2}$, S. L. HUMENYUK ${ }^{2}$, V. V. MANKO \\ ${ }^{1}$ Ivan Franko National University of Lviv, Ukraine; \\ ${ }^{2}$ SSRCI of Veterinary Medicinal Products and Feed Additives, Lviv, Ukraine; \\ e-mail: romostapiv@gmail.com; vvmanko@Inu.edu.ua
}

The effect of long-term oral taurine administration to rats on activity of lactate dehydrogenase (LDH), its isozyme content and activity in the whole blood, liver, thigh muscle, brain and testes tissues were studied in the present work. For this purpose male Wistar rats with body weight 190-220 g were randomly divided into three groups, they were orally administered drinking water (control group) or taurine solution 40 and $100 \mathrm{mg}$ per $\mathrm{kg}$ of body weight ( groups I and II, respectively). The total lactate dehydrogenase activity was measured spectrophotometrically, the percentage content of isozymes was determined by electrophoresis in 7.5\% poliacrylamide gel with further staining according to J. Garbus. It was found that the total lactate dehydrogenase activity increased in all studied tissues. In testes of animals of both groups and in brain of group I animals, the total percentage contents of isozymes that are responsible for lactate production $(\mathrm{LDH} 4+\mathrm{LDH} 5)$ increased. In liver of animals of both groups and in whole blood of group II animals, the total percentage content of isozymes that produce pyruvate $(L D H 1+L D H 2)$ increased. In thigh muscle of both groups and in brain of group II animals the balance between $\mathrm{LDH} 1+\mathrm{LDH} 2$ and $\mathrm{LDH} 4+\mathrm{LDH} 5$ content did not differ from control values, though total lactate dehydrogenase activity was significantly higher, than that in the control group. Thus, the increase in the lactate dehydrogenase activity under long-term oral taurine administration in different rat tissues was found to be tissue- and dose-dependent and was caused by the increase in the content of different isozymes. Such increase in group I animals might be explained by adaptive mechanisms to hypoxia caused by high doses of taurine. For group II animals high doses of taurine were toxic and directly affected metabolic processes in the animal bodies.

Key words: taurine, lactate dehydrogenase (LDH), isozymes, whole blood, liver, thigh muscle, brain, testes.

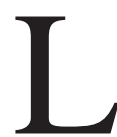
actate dehydrogenase (L-lactate: NAD-oxidoreductase EC 1.1.1.27) is an enzyme that catalyzes the conversion of lactate to pyruvate and the corresponding reverse reaction. Direct reaction occurs at high concentrations of lactate, the reverse reaction occurs in case of oxygen deficiency in the cell [1]. This enzyme is a heterotetramer composed of certain combinations of $\mathrm{M}$ - and $\mathrm{H}$-subunits. Different ratios of the subunits in various isozymes determine the affinity to lactate and pyruvate and hence their role in the direct or reverse reactions. There are five isozymes of lactate dehydrogenase LDH1-LDH5 contained in all tissues of vertebrates animals [2]. The first two isozymes have higher affinity for lactate and therefore, they predominate in the tissues well supplied with oxygen. LDH3 has the same affinity for pyruvate and lactate. LDH4 and LDH5 dominate in the tissues where glycolysis predominates [3]. LDH activity in blood plasma is a marker of plasma membrane integrity, and the increase in the LDH5 content in the liver indicates degenerative processes [4]. Lactate dehydrogenase activity and isozymes content in an organism are not constant values, and are altered during metabolism and under influence of various factors [1]. In particular, one of the factors that can influence their content is taurine, which is a sulphur containing free amino acid that regulates $\mathrm{Ca}^{2+}$-homeostasis and carbohydrate metabolism [5]. It was shown that taurine administration by mice on carbohydrate diet induced a decrease in the concentration of glucose in the blood and an increase in the content of ATP in the pancreas, consequent from increased insulin secretion [6]. This confirms the ability of taurine to affect 
glucose metabolism in the organism and, possibly, regulate the activity of enzymes associated with glycolysis. Adding taurine to neurons previously incubated with $\mathrm{MPP}^{+}$, a substance that causes neurons degeneration, lead to increased lactate dehydrogenase activity and ATP re-synthesis [7].

Since lactate dehydrogenase is one of the markers of metabolic functional stability, the aim of the study was to investigate the effect of long-term oral administration of taurine on the total lactate dehydrogenase enzyme activity and the content of its isozymes in different rat tissues.

\section{Materials and Methods}

Male Wistar rats were used in the experiments. The rats were 4.5 months old and had body weight of 190-220 $\mathrm{g}$ at the beginning of the experiment. Animal experiment was performed in accordance with European Convention for the Protection of Vertebrate Animals used for Experimental and Other Scientific Purposes and the law of Ukraine On the Protection of Animals Against Cruel Treatment. Animals were randomly assigned to three groups: one control group and two experimental groups. Over a 28 day period, the animals were daily administered in the esophagus with: control group drinking water, group I - solution of taurine $40 \mathrm{mg} /$ $\mathrm{kg}$, group II - solution of taurine $100 \mathrm{mg} / \mathrm{kg}$. First dose was selected because it induced recovery of the nervous system in mice after administration of ethanol per os [8]. Second dose is one fiftieth of $\mathrm{LD}_{50}$ and often used in studies of taurine detoxication effects [9-11]. The animals were decapitated on the $29^{\text {th }}$ day under light chloroform anesthesia and blood was collected in a tube with heparin. Liver, brain, testis and thigh muscle were isolated. After blood sampling, the number of erythrocytes was determined by colorimetry at $670 \mathrm{~nm}$ [12]. The hemoglobin content was determined by cyanmethemoglobin method at $540 \mathrm{~nm}[12]$.

Organs were homogenized using Potter-Elvehjem homogenizer at $4{ }^{\circ} \mathrm{C}$ in a ratio of $1 \mathrm{~g}$ of tissue in $5 \mathrm{ml}$ of sucrose solution $(250 \mathrm{mM})$. The homogenate was centrifuged for $15 \mathrm{~min}$ at $2000 \mathrm{~g}$ and the supernatant was collected. Lactate dehydrogenase activity in the whole blood and in the supernatant was determined by spectrophotometry and was derived from the rate of reduction of $\mathrm{NAD}^{+}$per mg of protein [13].

$\mathrm{LDH}$ isozyme composition was determined by electrophoresis in 7.5\% polyacrylamide gel (PAGE) followed by staining according J. Garbus [14]. Elec- trophoresis analysis was performed using software TotalLab (Fig. 1). Assuming that the activity of a specific isozyme was proportional to its percentage content, we calculated activity of each isozyme of lactate dehydrogenase $\left(a_{n}\right)$ by the formula:

$$
a_{n}=\frac{A \times[L D H n]}{100},
$$

where A is a total activity of lactate dehydrogenase ( $\mu \mathrm{M}$ of $\mathrm{NADH} /(\mathrm{min} \times \mathrm{mg}$ protein), $[\mathrm{LDHn}]$ is the content of the corresponding isozyme (\%).

To obtain suspension of isolated liver mitochondria, tissue was homogenized at $4{ }^{\circ} \mathrm{C}$ in a solution consisting of sucrose $250 \mathrm{mM}$, EGTA $1 \mathrm{mM}$, HEPES $10 \mathrm{mM}$; pH 7.2 [15]. The homogenate was centrifuged for $15 \mathrm{~min}$ at $2000 \mathrm{~g}$, and then the supernatant was collected and centrifuged for $20 \mathrm{~min}$ at $9000 \mathrm{~g}$. After the second centrifugation, the supernatant was discarded and the pellet was resuspended in a solution consisting of sucrose $250 \mathrm{mM}$, tris-Cl $25 \mathrm{mM}, \mathrm{KH}_{2} \mathrm{PO}_{4} 10 \mathrm{mM}$; pH 7.4 [16].

The rate of oxygen uptake by the liver mitochondria was determined by polarographic analysis in a thermostatic cell $\left(25^{\circ} \mathrm{C}\right)$. The rate of oxygen consumption was determined under endogenous respiration (the absence of exogenous substrates, $S_{1}$ state according to Chance), under addition of the oxidation substrates such as $\alpha$-ketoglutarate $(5 \mathrm{mM}$, $\mathrm{S}_{4}$ state), the substrate of oxidative phosphorylation ADP (200 nM, $S_{3}$ state) and after this phosphate acceptor was depleted $\left(S_{4}{ }^{\mathrm{ATP}}\right)$ [17].

The total protein concentration in tissues and mitochondrial suspension was determined by the Lowry assay [18] at $750 \mathrm{~nm}$ using a SF-46 spectrophotometer.

Statistical analysis of the obtained data was performed by variation statistics method using software "Microsoft Excel 2010". The data are presented as average values and error of the mean $(M \pm m)$. The significance of the data differences was calculated using Student $t$-test [19].

\section{Results and Discussion}

It was found that taurine affects the total enzymatic activity of lactate dehydrogenase in the studied tissues. In particular, in case of taurine long-term oral administration, the total enzyme activity in the blood of group I animals was higher than in the control by 59\% (Table 1). With increased total lactate dehydrogenase activity, the total percentage content of isoforms LDH1 and LDH2 in the blood of group I 


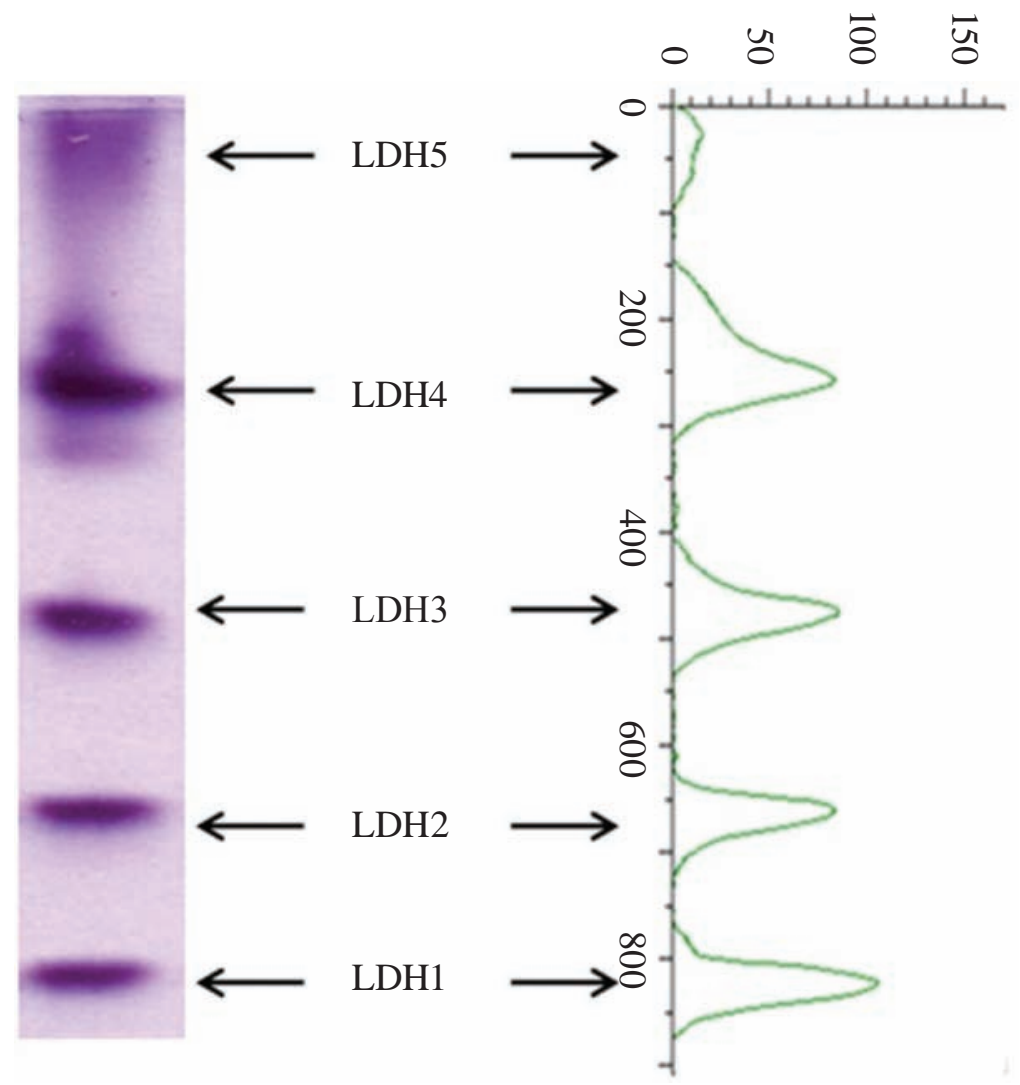

Fig. 1. Electrophoresis of lactate dehydrogenase isozymes (thigh muscle of the control animal)

animals decreased (Fig. 2, A). It might indicate reduced formation of pyruvate. However, the specific lactate dehydrogenase activity of various isozymes was assumed to be identical, then, according to our calculations, activities of not only LDH4 (by 286\%) and LDH3 (by 172\%) but also LDH2 (by $47 \%$ ) increased in the blood of group I animals (Table 2).

Such increase in total lactate dehydrogenase activity and activity of its individual isozymes in blood of the group I animals indicated intensification of metabolic processes (pyruvate was produced no less than in the control and possibly more, but lactate was produced even more). It may be due to an increased number of blood cellular components. Indeed, if the number of red blood cells in the control group was $(5.20 \pm 0.43) \times 10^{12} / l$, then it increased to $(7.95 \pm 0.28) \times 10^{12} / 1$ in the animals of group I $(P<0.01 ; n=4-5)$. At the same time, the

Ta ble 1. Effect of taurine on the total lactate dehydrogenase activity in rat tissues, $\mu M N A D H /(m i n \times m g$ of protein), $n=5$

\begin{tabular}{l|c|c|c}
\hline \multirow{2}{*}{ Organ } & \multicolumn{3}{|c}{ Animal group } \\
\cline { 2 - 4 } & Control & Group I & Group II \\
\hline Blood & $2.46 \pm 0.42$ & $3.91 \pm 0.44^{*}$ & $3.34 \pm 0.45$ \\
Liver & $0.83 \pm 0.07$ & $1.41 \pm 0.27$ & $1.20 \pm 0.12^{\#}$ \\
Muscles & $1.09 \pm 0.39$ & $3.58 \pm 0.91^{*}$ & $1.61 \pm 0.37^{\star}$ \\
Testes & $10.15 \pm 1.52$ & $14.67 \pm 1.66$ & $15.81 \pm 0.44^{\# \#}$ \\
Brain & $10.33 \pm 0,72$ & $18.37 \pm 2.28^{* *}$ & $18.86 \pm 1.21^{\# \# \#}$ \\
\hline
\end{tabular}

Notes (here and further): * statistically significant differences between control group and group I animals, \# between control group and group II animals, \& between groups I and II $\left({ }^{*} P<0.05\right.$, ** $P<0.01$, ${ }^{* * *} P<0.001$; ${ }^{*} P<0.05$, ${ }^{\# \#} P<0.01$, \#\#\# $P<0.001$; \& $P<0.05$, \&\& $P<0.01$, \&\&\& $\left.P<0.001\right)$. 
Ta b le 2. Effect of taurine on the lactate dehydrogenase isozymes activity in rat tissues, $\mu M N A D H /(\min \times m g$ of protein), $n=4$

\begin{tabular}{|c|c|c|c|c|c|}
\hline \multirow{2}{*}{$\begin{array}{l}\text { Animal } \\
\text { group }\end{array}$} & \multicolumn{5}{|c|}{ Isozyme } \\
\hline & LDH1 & LDH2 & LDH3 & LDH4 & LDH5 \\
\hline \multicolumn{6}{|c|}{ Blood } \\
\hline Control & $0.75 \pm 0.12$ & $0.75 \pm 0.10$ & $0.25 \pm 0.05$ & $0.28 \pm 0.06$ & $0.63 \pm 0.12$ \\
\hline I & $0.91 \pm 0.10$ & $1.10 \pm 0.10^{*}$ & $0.68 \pm 0.05^{* *}$ & $1.08 \pm 0.09 * * *$ & $0.47 \pm 0.04$ \\
\hline II & $1.35 \pm 0.08^{\# \#, \&}$ & $1.20 \pm 0.11^{\#}$ & $0.47 \pm 0.07^{\#, \&}$ & $0.17 \pm 0.03^{\& \& \&}$ & $0.64 \pm 0.07$ \\
\hline \multicolumn{6}{|c|}{ Liver } \\
\hline Control & $0.15 \pm 0.01$ & $0.17 \pm 0.01$ & $0.27 \pm 0.02$ & $0.25 \pm 0.02$ & $0.040 \pm 0.002$ \\
\hline I & $0.26 \pm 0.03^{*}$ & $0.21 \pm 0.02$ & $0.29 \pm 0.05$ & $0.27 \pm 0.03$ & $0.13 \pm 0.01 * * *$ \\
\hline II & $0.32 \pm 0.03^{\# \#}$ & $0.20 \pm 0.03$ & $0.29 \pm 0.03$ & $0.27 \pm 0.04$ & $0.18 \pm 0.01^{\# \# \#, \& \&}$ \\
\hline \multicolumn{6}{|c|}{ Muscle } \\
\hline Control & $0.14 \pm 0.02$ & $0.16 \pm 0.02$ & $0.21 \pm 0.04$ & $0.28 \pm 0.06$ & $0.010 \pm 0.001$ \\
\hline I & $0.44 \pm 0.08^{* *}$ & $0.55 \pm 0.09 * *$ & $0.64 \pm 0.11^{*}$ & $0.91 \pm 0.20^{*}$ & $0.36 \pm 0.10^{*}$ \\
\hline II & $0.26 \pm 0.05$ & $0.27 \pm 0.06^{\&}$ & $0.25 \pm 0.04^{\& \&}$ & $0.39 \pm 0.09$ & $0.13 \pm 0.03^{\# \#}$ \\
\hline \multicolumn{6}{|c|}{ Brain } \\
\hline Control & $2.32 \pm 0.15$ & $2.21 \pm 0.18$ & $2.55 \pm 0.21$ & $2.28 \pm 0.10$ & $0.42 \pm 0.05$ \\
\hline I & $5.53 \pm 0.54^{* *}$ & $3.92 \pm 0.44^{*}$ & $4.40 \pm 0.44^{* *}$ & $5.20 \pm 0.39 * * *$ & $1.31 \pm 0.22^{\# \#}$ \\
\hline II & $4.94 \pm 0.29^{\# \# \#}$ & $4.14 \pm 0.30^{\# \#}$ & $4.38 \pm 0.35^{\# \#}$ & $4.42 \pm 0.53^{\# \# \#}$ & $1.18 \pm 0.16^{* *}$ \\
\hline \multicolumn{6}{|c|}{ Testes } \\
\hline Control & $2.76 \pm 0.63$ & $2.66 \pm 0.79$ & $1.88 \pm 0.35$ & $1.88 \pm 0.35$ & $0.10 \pm 0.01$ \\
\hline I & $4.69 \pm 1.42 *$ & $3.13 \pm 0.86$ & $2.24 \pm 0.65$ & $2.08 \pm 0.48$ & $1.55 \pm 0.27 * * *$ \\
\hline II & $2.48 \pm 0.25^{\&}$ & $3.86 \pm 0.40^{\#}$ & $3.34 \pm 0.47^{\# \#, \&}$ & $4.00 \pm 0.40^{\# \#, \& \&}$ & $2.06 \pm 0.36^{\# \# \#}$ \\
\hline
\end{tabular}

hemoglobin content in the blood of group I animals $(93.40 \pm 3.28 \mathrm{~g} / 1)$, despite an increase in the number of erythrocytes, did not differ from the control animals $(101.41 \pm 8.41 \mathrm{~g} / \mathrm{l})$. Such alterations may indicate a compensatory response of the body to the development of functional hypoxia. A sharp increase in LDH4 activity may also be an evidence of the development of hypoxic condition in the body.

The total activity of lactate dehydrogenase in the blood of group II animals did not significantly differ from control values. At the same time, a shift of the ratio between the isozymes groups towards the conversion of lactate to pyruvate was observed. This was confirmed by an increase in the calculated activity of LDH1 and LDH2 of 80 and $60 \%$, respectively. Rather significant increase $(88 \%)$ in the activity of LDH3 (isozyme, which may convert lactate to pyruvate and vice versa equally) was also observed. A number of erythrocytes and hemoglobin did not differ from control animals and were $(5.76 \pm 0.42) \times 10^{12} / 1$ and $99.5 \pm 8.16 \mathrm{~g} / \mathrm{l}$, respectively.
Therefore, we concluded that although lactate dehydrogenase activity in blood of the group II animals was also increased, the mechanisms and the effectiveness of this growth were different.

Blood parameters directly dependent on the liver condition and taurine is synthesized and utilized directly in it. Therefore, it is important to investigate the effect of this compound on lactate dehydrogenase activity in the liver. Especially because lactate dehydrogenase plays an important role in the liver, in particular, converts lactate to pyruvate [1].

It was found that taurine administration led to the increase in the lactate dehydrogenase activity in the liver only in rats of group II by $45 \%$ compared to the control (Table 1). The total amount of LDH1 and LDH2 in the liver tissue in both experimental groups under the influence of taurine increased (Fig. 2, B), owing to, primarily, LDH1 which activity was increased by 73 and $113 \%$, respectively (Table 2). This indicated higher rate of conversion of lactate to pyruvate in hepatocytes and thus higher level of 


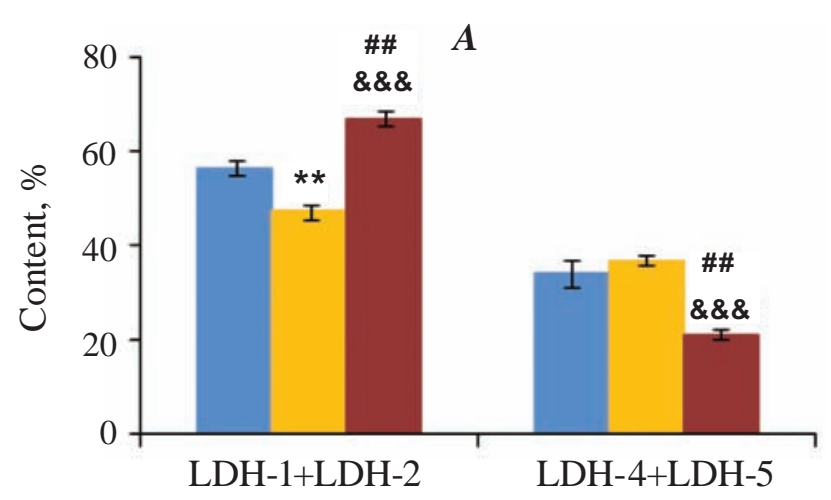

C

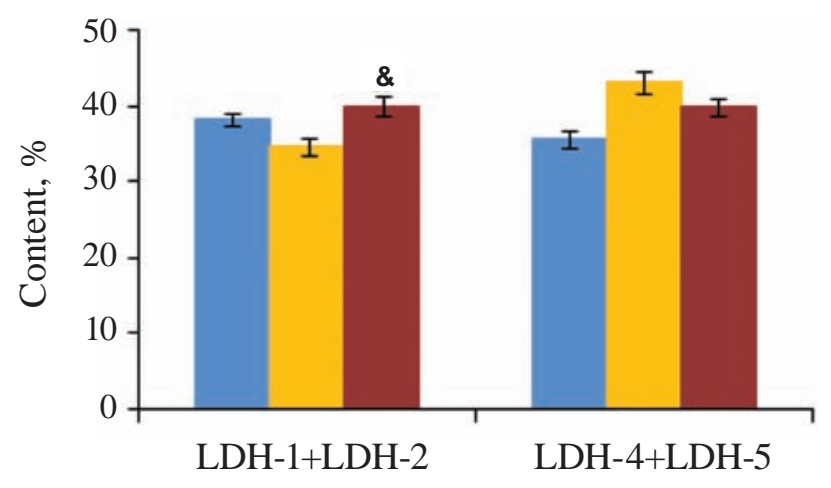

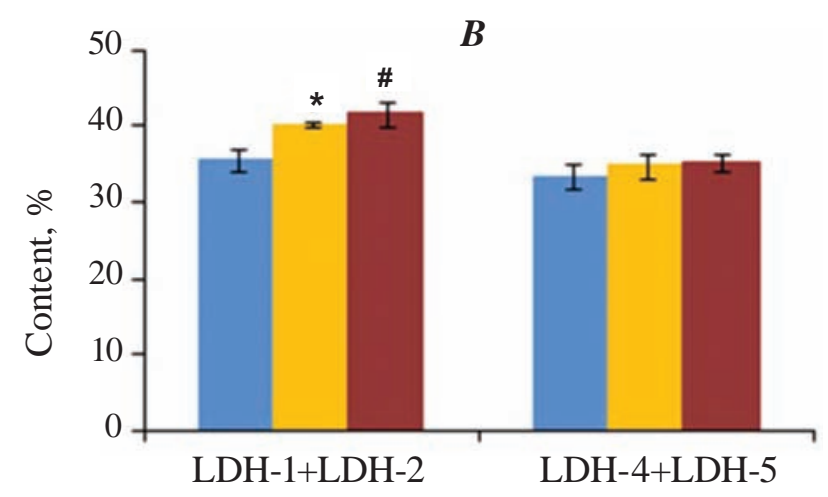

D

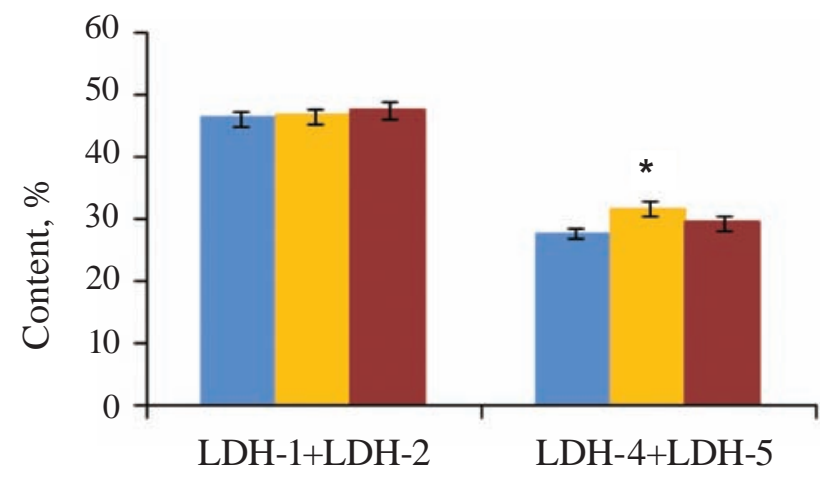

$\boldsymbol{E}$

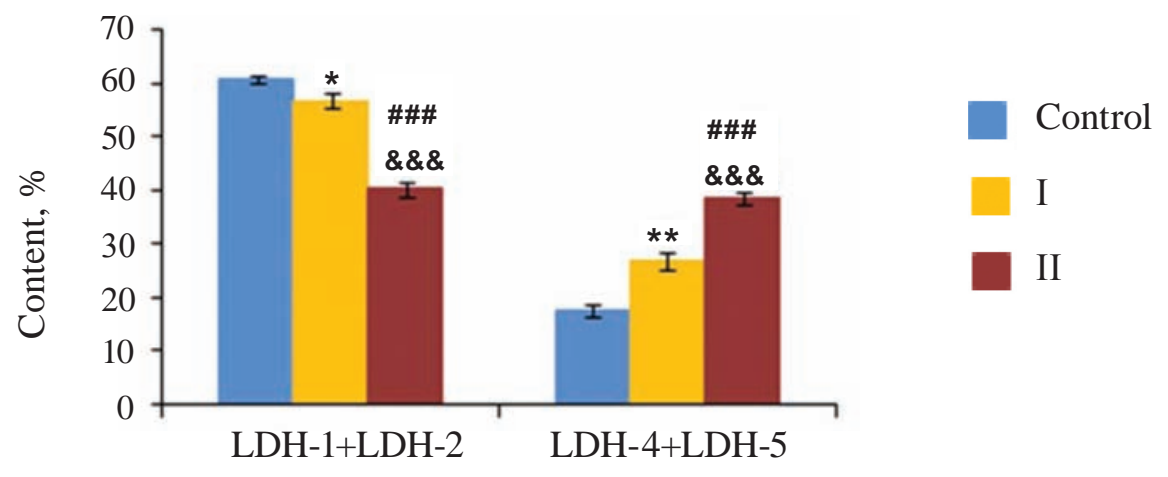

Fig. 2. Total percentage contents of lactate dehydrogenase isozymes in tissues of control, groups I and II animals, which characterizes level of aerobic $(L D H 1+L D H 2)$ and anaerobic $(L D H 4+L D H 5)$ metabolisms; $n=4$ (A -whole blood, B - liver, C - thigh muscle, D-brain, E-testes, I-first animal group, II-second animal group)

oxidation processes. At the same time, the calculated LDH5 activity also increased significantly in the liver of animals of groups I and II by 225 and 350\%, respectively. However, even such increase in LDH5 activity did not affect the ratio between the oxygendependent and oxygen-independent isozymes of lactate dehydrogenase.

Increase in the activity of the fifth isozyme of lactate dehydrogenase is a marker of possible cell damage [10]. Higher rate of oxygen-dependent me- tabolism in the liver, which is partially consequent from activation of the first isozyme of lactate dehydrogenase, may have caused acceleration of free radical oxidation that lead to cell damage and increase in the fifth isozyme activity. Alternatively, the increase in LDH5 activity may be an adaptive response to excessive amounts of lactate in the tissue.

Like in the liver, oral administration of taurine led to increased lactate dehydrogenase activity in thigh muscle tissue of group I animals by $230 \%$ 
(Table 1). At the same time, the total content of LDH1 and LDH2 as well as LDH4 and LDH5 did not significantly alter (Fig. 2, B). In this case, taurine caused the increase in the synthesis of all enzyme isoforms, those that were responsible for the formation of pyruvate as well as those that produced lactate (Table 2). However, the increase in LDH4 and LDH5 activity was more pronounced, which indicated the impossibility of utilization of all pyruvate in muscle tissue. This condition occurs in case of oxygen deficiency in the muscles and the formed lactate is transported to the liver where it is converted into pyruvate [1].

In the muscle of group II animals, only LDH5 activity increased significantly, although its contribution to the total enzyme activity remained low. It also indicated the acceleration of glycolysis in the muscle fibers of group II animals.

The substantial changes in the activity of lactate dehydrogenase under the action of taurine were observed in the rat brain. The activity increased in the animals of groups I and II by 78 and $83 \%$, respectively, compared to the control (Table 1). At the same time, in the brain (like in muscles) of group I animals, the total content of LDH4 and LDH5 significantly increased (Fig. 2, D). Considering this, a significant increase (at least 1.5-2-fold) in the calculated activity of all isozymes (like in muscles) in group I animals was observed. Almost the same increase (in contrast to muscles) was observed in group II animals (Table 2).

The increase in lactate dehydrogenase activity and alterations in the content of its isozymes in rat brain tissue of the studied groups indicated an intensification of the processes of glucose utilization and an increase in the enzyme synthesis. However, the ratio between the content of isozymes in group II did not differ from that in the control, but shifted in group I animals and the increase in content of LDH4 and LDH5 was observed. Such changes may occur upon the reduction of oxygen content to which the brain is sensitive [20].

Like in the brain, the total enzymatic activity in testes was high in the control group, but its alterations under the action of taurine were statistically significant only in group II (Table 1). The ratio of lactate dehydrogenase isozymes in animals of both studied groups under the influence of taurine shifted toward increased content of LDH4 and LDH5 (Fig. 2, $E$ ). Less pronounced increase in calculated isozymes activity in the animals of both studied groups was observed. Nevertheless, the increase in LDH5 activity in group I, as well as LDH4 and LDH5 activities in group II indicated an increase in lactate synthesis in the testes and hence the possible development of hypoxia (Table 2).

Thus, upon long-term oral taurine administration, the total lactate dehydrogenase activity in rats of both experimental groups increased in all studied tissues. Investigation of neurodegenerative processes in vitro using toxin $\mathrm{MPP}^{+}$showed that taurine can restore the lactate dehydrogenase activity [7]. This study reported that $\mathrm{MPP}^{+}$decreased the activity of lactate dehydrogenase and enzymatic activity was restored during the subsequent incubation with taurine for $30 \mathrm{~min}$ [7]. However, it is more likely that taurine affects the activity of lactate dehydrogenase by increasing glucose utilization rate and hence increasing the concentration of its corresponding substrates. This is consistent with the results of studies in mice that received carbohydrate diet. Adding taurine to drinking water led to an intensification of insulin secretion and lowering blood glucose level [4].

The total percentage content of isozymes LDH4 and LDH5 increased in the brain and testes of group I animals. At the same time, the calculated activity of these isozymes also increased. This indicated an increase in production of lactate, which was evidently transported with blood to the liver, where the calculated activity of LDH1 increased and this isozyme converted lactate to pyruvate. However, in the liver the calculated activity of LDH5 producing lactate also increased. Perhaps the rate of pyruvate synthesis was too high for its usage and therefore, such increase in LDH5 activity might be an adaptive reaction to high pyruvate concentration.

In favor of the assumption of such process at long-term oral administration of taurine might serve the results of research of NADH-dependent part of mitochondrial respiration in rat liver (Fig. 3). In particular, it was found that oxygen uptake increased 2-4-fold in the group I animals in all respiration states (according to Chance).

Long-term administration of taurine also caused an increase in the calculated activities of isozymes in group II animals. However, this effect had a different character and mechanism, whereas the ratio between the total percentage contents of isozymes in the brain, muscle and testes did not change. As a consequence, lactate was not accumulated in the tissues in a large quantity. Indirectly, this assumption was confirmed by a decrease in the rate 

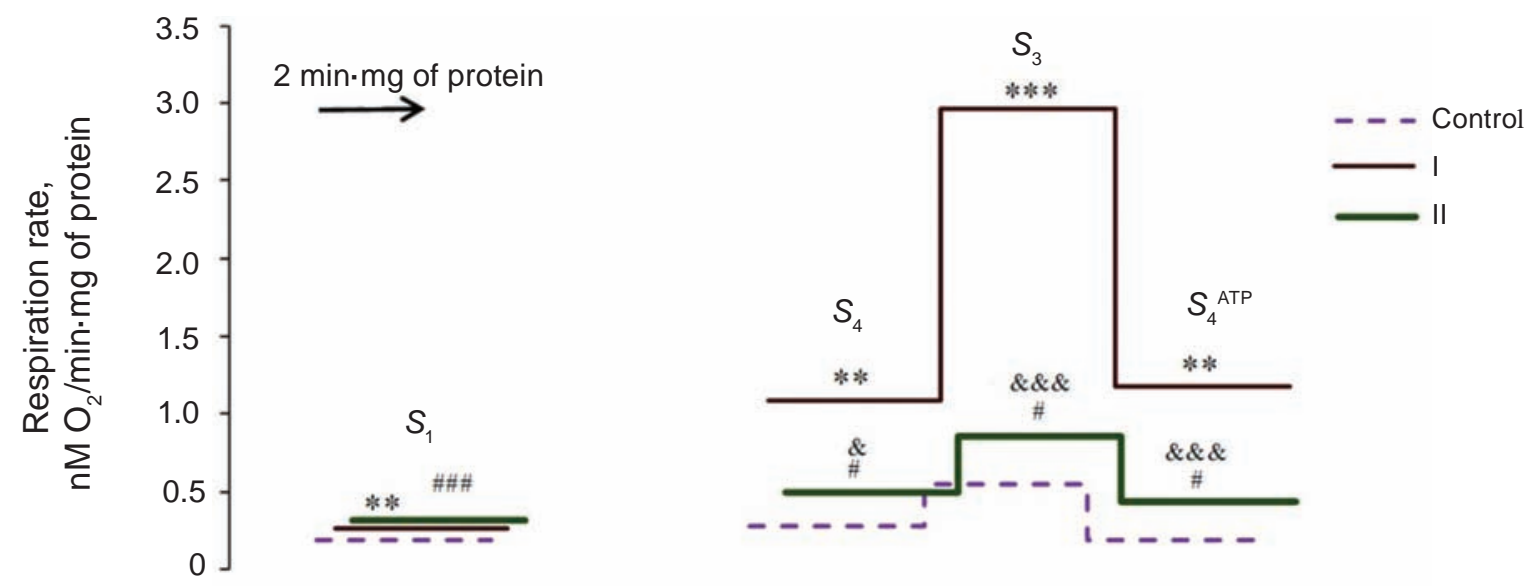

Fig. 3. Level of oxygen consumption by rat liver mitochondria during long-term taurine administration: $S_{1}$ - endogenous respiration, $S_{4}$ - respiration at oxidation of exogenous $\alpha$-ketoglutarate $(1 \mathrm{mM}), S_{3}-A D P$ stimulated respiration (200 nM) with exogenous $\alpha$-ketoglutarate (phosphorylation), $S_{4}^{\text {ATP }}-A D P$ depletion (post-phosphorilation respiration); phosphorylation time (min.mg of protein) was calculated as a product of time of $S_{3}$ state and the amount of mitochondrial proteins $(n=4)$

of oxygen uptake by liver mitochondria in group II animals. At the same time, the calculated activities of isozymes LDH1 and LDH2 were increased in blood, which indicated an increase in oxygendependent metabolism. Perhaps this effect may be a result of the increased number of reticulocytes in the blood.

The percentage ratio of isozymes in brain tissue of the studied animals remained almost unchanged, which indicated an increase in the synthesis of all five forms of lactate dehydrogenase. And, thus, it might point to a direct effect of taurine on enzyme synthesis and its involvement in the regulation of synthesis of both mitochondrial and cellular proteins.

We concluded that long-term oral taurine administration caused an increase in lactate dehydrogenase activity in the blood, liver, skeletal muscle, brain and testes. However, the mechanisms of this increase, alterations of isozymes composition of lactate dehydrogenase and physiological consequences that were caused by this increase depended both on the dose of taurine and the type of the tissue. 


\section{АКТИВНІСТЬ ТА ІЗОЗИМНИЙ СКЛАД ЛАКТАТДЕГІДРОГЕНАЗИ ЗА ТРИВАЛОГО ПЕРОРАЛЬНОГО ВВЕДЕННЯ ТАУРИНУ ЩУРАМ}

\author{
Р. Д. Остапів ${ }^{1,2}$, С. Л. Гуменюк ${ }^{2}$ \\ B. В. Манько ${ }^{1}$ \\ ${ }^{1}$ Львівський національний університет \\ імені Івана Франка, Україна; \\ ${ }^{2}$ ДНДКІ ветеринарних препаратів та \\ кормових добавок, Львів, Україна; \\ e-mail: romostapiv@gmail.com; \\ vvmanko@lnu.edu.ua
}

Мета роботи - дослідити активність лактатдегідрогенази, відсотковий вміст їі ізозимів та їхню активність у цільній крові і тканинах печінки, стегнового м'яза, головного мозку та сім'яників щурів за тривалого перорального введення таурину. Для цього самців щурів лінії Wistar масою 190-220 г розділили на три дослідні групи, а потім вводили питну воду (контрольна група) або розчин таурину в розрахунку 40 та 100 мг/кг маси тіла (I та II групи). Сумарну активність лактатдегідрогенази визначали спектрофотометрично, відсотковий вміст ізозимів - 3 використанням електрофорезу в 7,5\%-му поліакриламідному гелі з подальшим фарбуванням за J. Garbus. Виявлено, що у всіх досліджених тканинах збільшувалась загальна активність лактатдегідрогенази. У сім'яниках тварин обох дослідних груп та в мозку тварин групи I зростала сума відсоткового вмісту ізозимів, що відповідають за утворення лактату (ЛДГ4+ЛДГ5). У печінці тварин обох дослідних груп та у цільній крові тварин групи II, навпаки, збільшився відсотковий вміст ізозимів, що продукують піруват (ЛДГ1+ЛДГ2). У м'язах тварин обох дослідних груп та у мозку тварин групи II рівновага між вмістом ЛДГ1+ЛДГ2 та ЛДГ4+ЛДГ5 не відрізнялась від контрольних значень, хоча сумарна активність ензиму була істотно вищою, ніж у контролі. Отже, зростання активності лактатдегідрогенази в різних тканинах щурів за тривалого введення таурину $\epsilon$ тканиноспецифічним та дозозалежним і спричинене збільшенням вмісту різних ізозимів. Таке зростання у тварин групи I лежить в основі адаптаційних механізмів до гіпоксії, спричиненої високими дозами таурину. Для тварин групи II великі дози таурину є токсичними i прямо впливають на процеси в організмі.
К л ю чо в і слов а: таурин, лактатдегідрогеназа, ізозими, цільна кров, печінка, стегновий м'яз, мозок, сім'яники.

\section{АКТИВНОСТЬ И ИЗОЗИМНЫЙ СОСТАВ ЛАКТАТДЕГИДРОГЕНАЗЫ ПРИ ДОЛГОСРОЧНОМ ПЕРОРАЛЬНОМ ВВЕДЕНИИ ТАУРИНА КРЫСАМ}

\author{
Р. Д. Остапив ${ }^{1,2}$, С. Л. Гуменюк ${ }^{2}$, \\ B. В. Манько
}
${ }^{1}$ Львовский национальный университет имени Ивана Франко, Украина;
${ }^{2}$ ГНИКИ ветеринарных препаратов и кормовых добавок, Львов, Украина; e-mail: romostapiv@gmail.com; vvmanko@lnu.edu.ua

Цель работы - исследовать влияние длительного перорального введения таурина на активность лактатдегидрогеназы, содержание ее изозимов и их активность в цельной крови и тканях печени, бедренных мышц, головного мозга и семенников крыс. Для этого самцов крыс линии Wistar массой 190-220 г разделили на три экспериментальные группы, а потом перорально вводили питьевую воду (контрольная группа) или раствор таурина в расчете 40 и 100 мг/ кг массы тела (I и II группы). Суммарную активность лактатдегидрогеназы определяли спектрофотометрически, содержание изозимов - с использованием электрофореза в 7,5\%-ом полиакриламидном геле с последующим окрашиванием по J. Garbus. Обнаружено, что во всех исследованных тканях увеличилась общая лактатдегидрогеназная активность. При этом, в семенниках животных обеих групп и в мозгу крыс группы I росла сумма процентного содержания изозимов, отвечающих за образование лактата (ЛДГ4+ЛДГ5). В противоположность этому в печени крыс обеих групп и в цельной крови крыс группы II увеличилось содержание изозимов, продуцирующих пируват (ЛДГ1+ЛДГ2). В мышцах крыс обеих исследовательских групп и в мозгу животных группы II равновесие между содержанием ЛДГ1+ЛДГ2 и ЛДГ4+ЛДГ5 не отличалось от контрольных значений, хотя суммарная лактатдегидрогеназная активность была значительно выше, чем в контроле. Таким образом, рост лактатдегидрогеназной активности в различных тканях крыс при длительном перо- 
ральном введении таурина является тканеспецифическим и дозозависимым и вызван увеличением содержания различных изозимов. Такой рост у животных группы I лежит в основе адаптационных механизмов к гипоксии, вызванной высокими дозами таурина. Для животных группы II большие дозы таурина являются токсичными и прямо влияют на процессы в организме.

К л ю ч е в ы е л о ва: таурин, лактатдегидрогеназа, изозим, цельная кровь, печень, бедренная мышца, мозг, семенники.

\section{References}

1. Kopperschläger G., Kirchberger J., Methods for the separation of lactate dehydrogenases and clinical significance of the enzyme. J. Chromatogr. B. Biomed. Sci. Appl. 1996;684(1-2):25-49.

2. Lossos I. S., Intrator O., Berkman N., Breuer R. Lactate dehydrogenase isoenzyme analysis for the diagnosis of pleural effusion in haemato-oncological patients. Respir. Med. 1999;93(5):338-341.

3. Wuntch T., Chen R. F., Vesell E. S. Lactate dehydrogenase isozymes: kinetic properties at high enzyme concentrations. Science. 1970;167(3914):63-65.

4. Koukourakis M. I., Giatromanolaki A., Sivridis E. Lactate dehydrogenase-5 (LDH-5) overexpression in non-small-cell lung cancer tissues is linked to tumour hypoxia, angiogenic factor production and poor prognosis. Br. J. Can. 2003;89(5):877-885.

5. Huxtable R. J. Physiological actions of taurine. Phys. Rev. 1992;72(1):101-163.

6. Ribeiro R. A., Bonfleur M. L., Amaral A. G., Vanzela E. C., Rocco S. A., Boschero A. C., Carneiro E. M. Taurine supplementation enhances nutrient-induced insulin secretion in pancreatic mice islets. Diabetes Metab. Res. Rev. 2009;25(4):370-379.

7. O’Byrne M. B., Tipton K. F. Taurine-induced attenuation of MPP1 neurotoxicity in vitro: a possible role for the GABA(A) subclass of GABA receptors. J. Neurochem. 2000;74(5):2087-2093.

8. Vohra Bh. P., Hui X. Improvement of impaired memory in mice by taurine. Neural Plast. 2000;7(4):245-259.
9. Erdem A., Gündogan N. Ü., Usubütün A. The protective effect of taurine against gentamicinindused acute tubular necrosis in rats. Nephrol. Dial. Transplant. 2000;15(8):1175-1182.

10. Zhang1 X., Tu Sh., Wang Y., Xu B., Wan F. Mechanism of taurine-induced apoptosis in human colon cancer cells. Acta Biochim. Biophys. Sin. 2014;46:261-272.

11. Aly H. A., Khafagy R. M. Taurine reverses endosulfan-induced oxidative stress and apoptosis in adult rat testis. Food Chem. Toxicol. 2014;64:1-9.

12. Levchenko V. I., Golovaha V. I., Kondrahin I. P. Methods of clinical laboratory diagnostics of animal diseases. Kyiv: Agrarna Osvita, 2010. P. 271-292. (in Ukrainian).

13. Holod V. M., Kurdeko A. P. Clinical biochemistry: tutorial in 2 tomes. Vitebsk, 2005. V. 2. P. 20. (In Russian).

14. Garbus J. Serum malate dehydrogenase isoenzymes as indicators of severe cellular injury. Clin. Chim. Acta. 1971;35(2):502-504.

15. Kondrashova M. N. Transaminase cycle of substrate oxidation in cell, as an adaptation mechanism to hypoxia. Pharmac. Correc. Hурох. Stat. 1989;1:51-70.

16. Della-Morte D., Dave K. R., DeFazio R. A., Bao Y. C., Raval A. P., Perez-Pinzon M. A. Resveratrol pretreatment protects rat brain from cerebral ischemic damage via a sirtuin 1-uncoupling protein 2 pathway. Neuroscience. 2009;159(3):993-1002.

17. Chance B., Williams G. R. Respiratory enzymes in oxidative phosphorilation. III. The steady state. J. Biol. Chem. 1955;217(1):409-27.

18. Lowry O. H., Rosebrough N. J., Farr A. L., Randall R. J. Protein measurement with Folin phenol reagent. J. Biol. Chem. 1951;193(1):265275.

19. Derkach M. P., Gumenitskiy R. Ya., Chaban M. E. Course of variation statistics. Kyiv: Vishcha Shkola, 1977. 210 p. (in Ukrainian).

20. El Idrissi A. Taurine increases mitochondrial buffering of calcium: role in neuroprotection. Amino Acids. 2008;34(2):321-328.

Received 13.03.2015 